\title{
Kajian Status Hara N, P, K Tanah Pada Sawah Tadah Hujan (Studi Kasus Tiga Desa di Kecamatan Beringin)
}

\section{Study of The Nutrient Status of N, P, K In Rainfed Ricefields (Case Study of Three Villages in Beringin District)}

\author{
Arkhiadi Benauli* \\ Department of Agrotechnology, Faculty of Agriculture, Universitas Katolik Santo Thomas, Medan, Indonesia
}

*Corresponding author: Arkhiaditarigan@gmail.com

Received: March 11, 2021; Accepted: March 25, 2021; Published: April 1, 2021

\begin{abstract}
Soil fertility status describes soil characteristics and soil suitability with the plants to be cultivated. This study aims to identify the variable soil fertility that becomes an obstacle in several villages in the Beringin District. This research was conducted in the villages of Aras Kabu, Kelapa, and Serdang, Beringin District, Deli Serdang Regency. This research is descriptive using the survey method. Sampling of soil in the survey area was carried out sequentially with a purposive random sampling method. The results showed that the total $\mathrm{N}$ status in the three villages was classified as low. Where the total $\mathrm{N}$ value in Aras Kabu village was $0.13 \%$, Kelapa village $0.12 \%$ and Serdang village was $0.21 \%$. Phosphorus in the research field is classified as high. In the village of Aras, the district was $19.57 \mathrm{ppm}$, Kelapa village $19.27 \mathrm{ppm}$ and Serdang village $13.19 \mathrm{ppm}$. The $\mathrm{K}_{2} \mathrm{O}$ value in the study area was also low, where the village of Aras Kabu was only $19.96 \mathrm{mg} \mathrm{K} \mathrm{K}_{2} \mathrm{O} / 100 \mathrm{~g}$, Kelapa village $18.56 \mathrm{mg} \mathrm{K}{ }_{2} \mathrm{O} / 100 \mathrm{~g}$ and Serdang village $25.47 \mathrm{mg}$ $\mathrm{K}_{2} \mathrm{O} / 100 \mathrm{~g}$. The use of $\mathrm{P}$ fertilizers can be reduced as an implication of the status of $\mathrm{P}$ nutrients available in high land, while to increase the low levels of $\mathrm{N}$ and $\mathrm{K}$ nutrients, it can be done by providing organic matter in the form of fertilizer (compost or cage) or returning post-harvest straw to the land.
\end{abstract}

Key words: fertilizer; paddy; soil survey

Cite this as: Benauli, A. (2021). Kajian status hara N, P, K tanah pada sawah tadah hujan (studi kasus tiga desa di Kecamatan Beringin). Agrosains : Jurnal Penelitian Agronomi, 23(1), 55-59. DOI: http://dx.doi.org/10.20961/agsjpa.v23i1.49239

\section{PENDAHULUAN}

Kebutuhan pangan nasional dapat terpenuhi dengan mengoptimalkan pemanfaatan lahan sawah tadah hujan yang potensial. Di Indonesia sendiri luas lahan sawah tadah hujan mencapai 3,71 juta hektar $( \pm 45,7 \%$ dari total lahan sawah) (Kasno et al., 2016). Kendala pada lahan sawah tadah hujan seperti ketersediaan air dari curah hujan, kesuburan tanah dapat diperbaiki dengan penerapan teknologi yang mampu meningkatkan produktifitas tanaman. Produktifitas padi sawah tadah hujan relatif rendah yakni sekitar 3,0-3,5 ton/hektar (Balingtan, 2015).

Padi merupakan salah satu tanaman pangan pokok hampir setengah dari populasi dunia. Oleh karena itu, produksi beras harus ditingkatkan secara signifikan untuk memenuhi kebutuhan penduduk dunia yang terus berkembang. Penerapan varietas unggul, penggunaan pupuk yang bijaksana, dan irigasi dengan praktik pengelolaan yang tepat dapat membantu meningkatkan produktivitas padi (Gairhe et al., 2018). Namun ketidakseimbangan nutrisi akan menyebabkan penurunan hasil gabah dan keuntungan bersih hasil panen (Wattoo et al., 2018).

Pengelolaan lahan terpadu yang harus dilakukan untuk meningkatkan hasil padi diantaranya pengelolaan air, perbaikan kesuburan tanah melalui pemberian bahan pembenah tanah, pencegahan hama dan penyakit, rotasi tanaman, pengelolaan bahan organik tanah dan pemupukan yang dilakukan sesuai dengan karakteristik tanah dan kebutuhan tanaman (Fageria, 2001). Survei tanah merupakan pekerjaan pengumpulan data kimia, fisik, dan biologi di lapangan maupun di laboratorium, dengan tujuan pendugaan penggunaan lahan umum maupun khusus. Tujuan dari survei tanah adalah mengklasifikasi, menganalisis, memetakan tanah dan mengelompokkan tanah-tanah yang sama atau hampir sama sifatnya ke dalam satuan peta tanah tertentu. Informasi pada peta status N, P, dan K dapat dijadikan dasar untuk menentukan rekomendasi pemupukan padi sawah yang tepat guna (Supriyadi et al., 2017).

Status kesuburan tanah sangat ditentukan oleh faktor alam seperti bahan induk, iklim, dan umur tanah serta kondisi sosial ekonomi seperti ada tidaknya diberikan pemupukan pada lahan sawah (Boansi, 2014). Penilaian status kesuburan tanah memberikan dasar untuk rekomendasi pemupukan spesifik lokasi untuk hasil tanaman yang optimal (Roland et al., 2014). Ketersediaan unsur hara di dalam tanah akan optimal pada tingkat kemasaman tanah mendekati netral. Pada kondisi masam hara tanah tidak tersedia karena sebagian besar terfiksasi oleh Al dan Mn pada lahan kering, Fe dan Mn pada lahan sawah. Sedangkan pada 
tanah bereaksi basa hara tidak tersedia karena terfiksasi oleh hara $\mathrm{Ca}$. Hara Fe yang tersedia pada kondisi masam, selain meracuni tanaman juga menyelubungi akar tanaman sampai tidak dapat menyerap hara tanah, serta dapat mengikat hara $P$ menjadi tidak tersedia. Pada kondisi basa, hara $P$ juga tidak tersedia bagi tanaman karena diikat oleh hara Ca (Kasno et al., 2016).

Sumatera Utara mempunyai luas lahan sawah sebesar 285.419 ha, terdiri dari lahan sawah irigasi 135.872 ha dan tadah hujan 149.547 ha (Dinas Pertanian Provinsi Sumatera Utara, 2014). Kabupaten Deli Serdang merupakan salah satu kabupaten di Sumatera Utara yang memiliki sawah tadah hujan yang paling luas yaitu 19.365 ha, setelah Kabupaten Langkat seluas 31.380 ha (Dinas Pertanian Provinsi Sumatera Utara, 2014). Lahan sawah tadah hujan merupakan sumberdaya fisik yang potensial untuk pengembangan tanaman komoditas padi. Permasalahan budidaya padi di lahan tadah hujan adalah produktivitas lebih rendah (berkisar antara 3,0-3,5 t/ha) dibandingkan dengan di lahan sawah irigasi (berkisar antara 6-7 t/ha) dan musim tanam padi satu kali dalam setahun, yaitu saat musim hujan saja (September-Desember). Kabupaten Deli Serdang merupakan salah satu kabupaten penyumbang beras untuk memenuhi kebutuhan pangan di Provinsi Sumatera Utara. Produksi padi sawah (GKP) Provinsi Sumatera Utara Tahun 2014 adalah sebesar 3.571.141 ton dan 448.479 ton $(12,56 \%)$ dari Kabupaten Deli Serdang. Hal ini menjadikan Kabupaten Deli Serdang mempunyai peranan yang cukup besar dalam mendukung ketahanan pangan di Sumatera Utara (BPS, 2014). Pengembangan lahan sawah menjadi relavan dengan peningkatan kebutuhan pangan nasional. Ada beberapa parameter dalam penetapan status kesuburan tanah, salah satunya : $(\mathrm{N}, \mathrm{P}, \mathrm{K})$ total tanah. Faktor pembatas pertumbuhan dapat diketahui dari hasil analisis tanah dan tanaman. Hara dalam tanah maupun tanaman yang berada di bawah batas kritis merupakan hara yang dapat menjadi faktor pembatas pertumbuhan dan hasil tanaman. Pengamatan pertumbuhan dan hasil tanaman di lapang juga dapat digunakan untuk menduga faktor pembatas pertumbuhan tanaman (Kasno et al., 2016). Kriteria apakah status unsur hara dalam tanah rendah, sedang, tinggi tergantung dari hasil analisis tanah yang dibandingkan dengan kebutuhan unsur hara tanaman. Adapun kriteria tersebut berdasarkan Pusat Penelitian Tanah Bogor (BP2K, 2012). Penelitian ini bertujuan mengidentifikasi variabel kesuburan tanah yang menjadi kendala di beberapa desa pada Kecamatan Beringin.

\section{BAHAN DAN METODE}

Penelitian ini dilaksanakan pada bulan Oktober 2020 di desa Aras Kabu, Kelapa dan Serdang, Kecamatan Beringin, Kabupaten Deli Serdang. Bahan yang digunakan dalam penelitian berupa sampel tanah inceptisol pada lahan sawah di desa Aras Kabu, Kelapa, dan Serdang, Kecamatan Beringin dan bahan kimia untuk analisis tanah. Alat untuk survei tanah meliputi pisau; kantong plastik; ring sampel tanah; timbangan dan alat tulis.

Pengambilan sampel tanah pada areal survei dilakukan secara sekuen dengan metode purposive random sampling, sehingga hasil yang diperoleh diharapkan dapat mencerminkan nilai sebenarnya
Pengambilan sampel tanah di lapangan dilakukan pada kedalaman antara $0-30 \mathrm{~cm}$ dari lapisan permukaan dengan menggunakan ring sampel/cincin. Setelah itu, sampel dan ring tersebut dibungkus dengan plastik, kemudian diikat menggunakan karet gelang agar tanah tetap utuh. Cincin/ring sampel yang berisi sampel tanah tersebut kemudian dibawa ke laboratorium untuk dianalisis lebih lanjut. Selain dengan pengamatan langsung, informasi pengelolaan tanah diperoleh dengan cara wawancara langsung dengan petani secara snow ball. Sifat-sifat kimia tanah yang dianalisis di laboratorium adalah $\mathrm{N}$-total tanah (metode Kjehdahl), Ptersedia (Metode Bray II) dan K-total Tanah (Metode Bray I ( $\mathrm{HCl} 25 \%)$

\section{HASIL DAN PEMBAHASAN \\ Kondisi Daerah Penelitian}

Menurut Dinas Kominfo Kabupaten Deli Serdang (2019), Kabupaten Deli Serdang secara administratif terdiri dari 22 Kecamatan, 14 Kelurahan dan 380 Desa. Luas wilayahnya yaitu $249.772 \mathrm{Ha}\left(2.497,72 \mathrm{~km}^{2}\right)$. Kabupaten Deli Serdang merupakan salah satu dari 33 Kabupaten/Kota yang ada saat ini di Provinsi Sumatera Utara. Berdasarkan letak geografisnya Kabupaten Deli Serdang berada pada Kawasan Pantai Timur Sumatera Utara yang berbatasan langsung dengan Selat Malaka. Secara geografis Kabupaten Deli Serdang terletak diantara koordinat $2^{\circ} 57^{\prime}$ "sampai dengan $3^{\circ} 16$ " Lintang Utara, dan 98 $33^{\circ}$ " sampai dengan 99²7" Bujur Timur. Wilayah Kabupaten Deli Serdang bagian utara berbatasan dengan Kabupaten Langkat dan Selat Malaka; bagian selatan berbatas dengan Kabupaten Karo dan Kabupaten Simalungun; bagian barat berbatas dengan Kabupaten Langkat dan Kabupaten Karo; sebelah timur berbatas dengan Kabupaten Serdang Bedagai. Kecamatan Beringin adalah salah satu kecamatan di Kabupaten Deli Serdang, Provinsi Sumatera Utara. Kecamatan Beringin memiliki luas $52,69 \mathrm{~km}^{2}$ atau $5.269 \mathrm{Ha}$ yg terdiri menurut 11 desa \& 89 dusun, menggunakan lbukota Kecamatan terletak pada Desa Karang Anyar. Desa terluas merupakan Desa Pasar VI Kuala Namu menggunakan luas daerah 8,90 $\mathrm{km}$ atau $890 \mathrm{Ha}$ \& desa terkecil merupakan Desa Sidourip menggunakan luas daerah 1,63 km atau 163 Ha. Wilayah Kecamatan Beringin bagian utara berbatasan dengan Kecamatan Pantai Labu; bagian timur berbatas dengan Kecamatan Pagar Merbau dan Kecamatan Pantai Cermin Kab. Serdang Bedagai; bagian selatan berbatas dengan Kecamatan Lubuk Pakam; sebelah barat berbatas dengan Kecamatan Beringin dan Kecamatan Batang Kuis. Berdasarkan kondisi topografinya, Kabupaten Deli Serdang terdiri dari tiga bagian kawasan yaitu Kawasan Dataran Pantai, terdapat seluas $\pm 63.002 \mathrm{Ha}(25,22 \%)$; Kawasan Dataran Rendah, terdapat seluas $\pm 80.265 \mathrm{Ha}(32,14 \%)$ termasuk Kecamatan Beringin; dan Kawasan Dataran Tinggi, terdapat seluas $\pm 106.506 \mathrm{Ha}(42,62 \%)$. Potensi Utama adalah: Pertanian Pangan, Perkebunan Besar, Perkebunan Rakyat, Peternakan, Industri, Perdagangan dan Perikanan Darat. Pada umumnya Kabupaten Deli Serdang berada pada ketinggian 0-500 meter diatas permukaan laut. Namun pada kawasan bagian Selatan terdapat wilayah dengan ketinggian diatas $500 \mathrm{~m}$ diatas permukaan laut. 


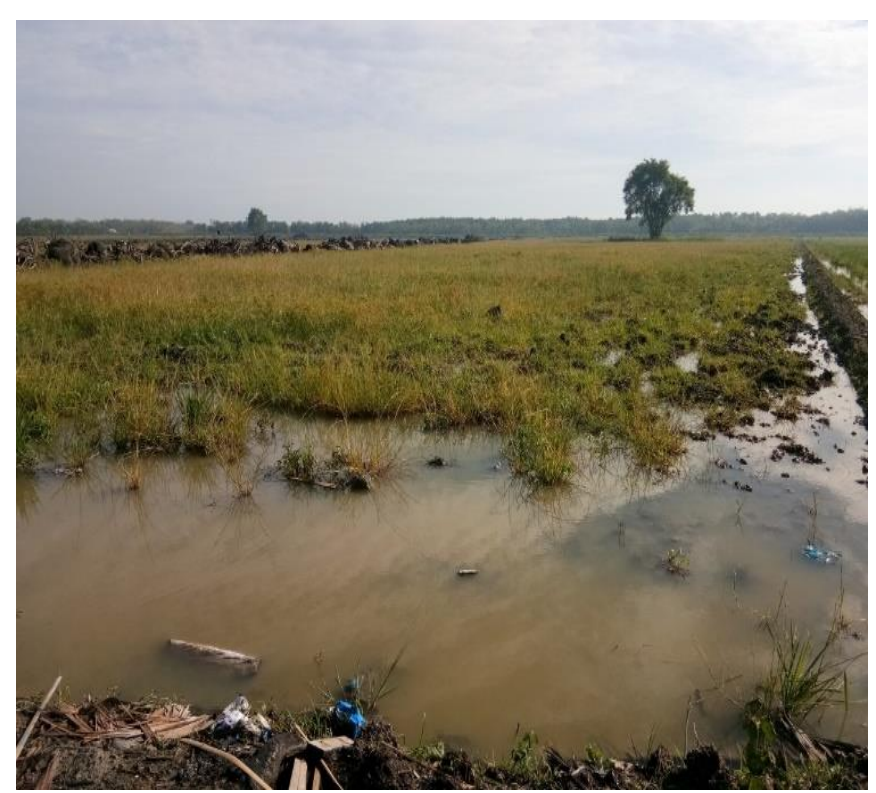

Gambar 1. Kondisi lahan sampel di desa Aras Kabu

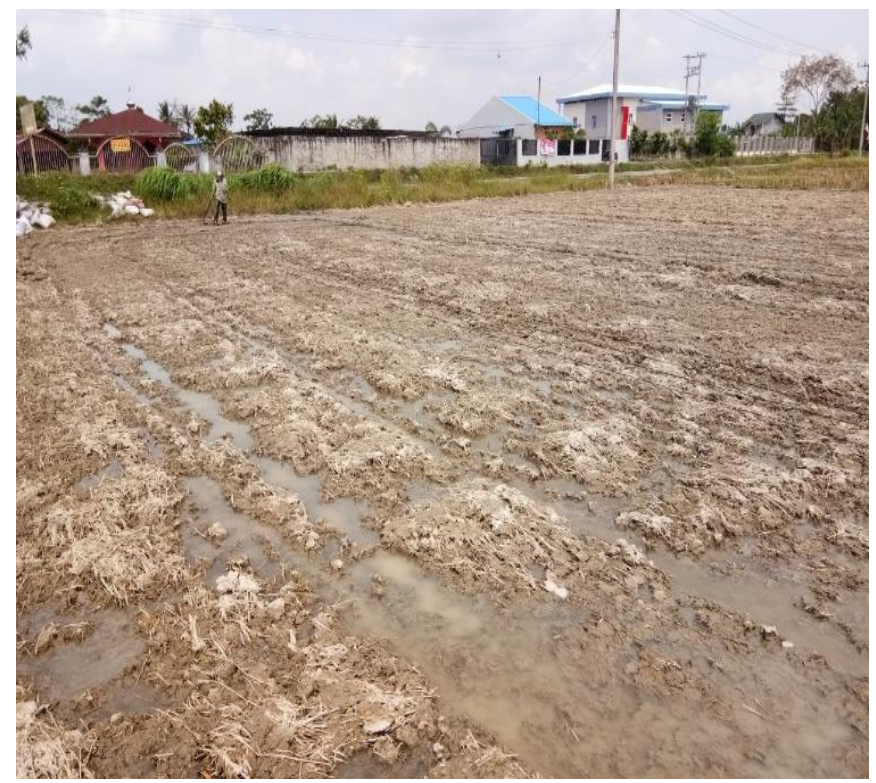

Gambar 2. Kondisi lahan sampel di desa Kelapa

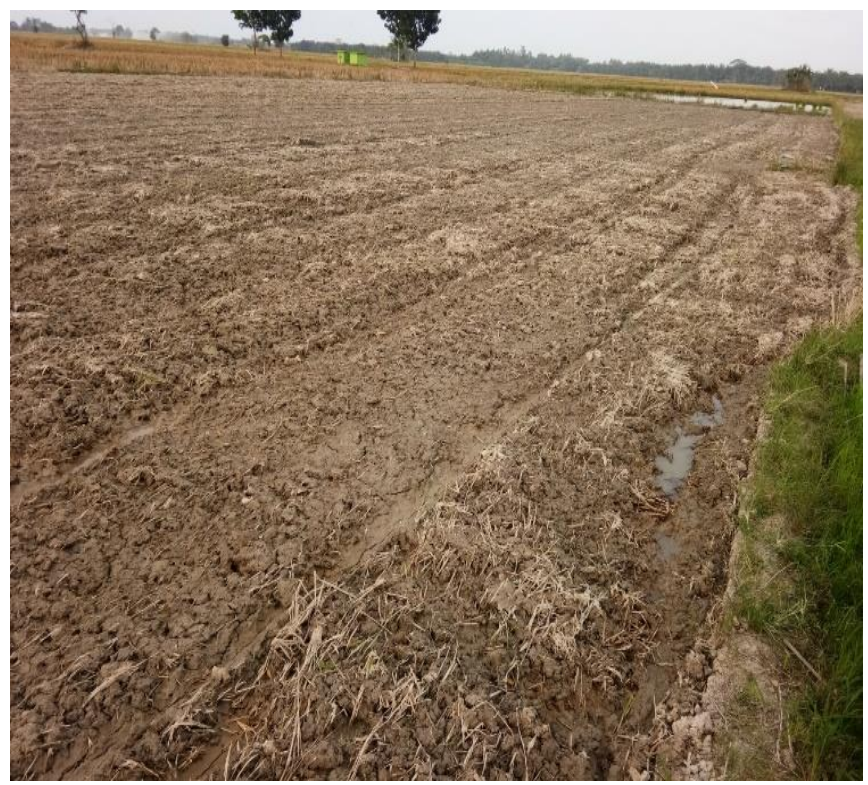

Gambar 3. Kondisi lahan sampel di desa Serdang
Menurut Dinas Kominfo Kabupaten Deli Serdang (2019), Kabupaten Deli Serdang mempunyai dua musim yaitu: musim hujan dan musim panas (kering). Suhu rata-rata perbulan minimun $23,9^{\circ} \mathrm{C}$ dan maksimun $32,4^{\circ} \mathrm{C}$. Sedangkan berdasarkan kemiringan lerengnya, pada dasarnya Kabupaten Deli Serdang memiliki wilayah yang relatif datar hingga bergelombang dengan kemiringan berkisar antara $0-15 \%$. Namun pada daerah tertentu, terdapat kemiringan yang relatif bergelombang hingga terjal dengan kemiringan lereng berkisar antara $15-40 \%$. Berdasarkan jenis tanah yang terdapat di Kecamatan Beringin yaitu tanah Hidromorfik kelabu, gley humus dan regosol terdapat seluas $57.294 \mathrm{Ha}$ yang tersebar pada bagian tengah wilayah kabupaten seperti di Kecamatan Hamparan Perak, Percut Sei Tuan, Batang Kuis, Beringin, Lubuk Pakam dan Pagar Merbau.

Berdasarkan jenis pengairan, lahan sawah di Kabupaten Deli Serdang terdiri dari lahan sawah irigasi, tadah hujan dan rawa lebak sedangkan lahan sawah pasang surut tidak ada. Luas lahan sawah Irigasi sebesar 24.010 ha, lahan sawah tadah hujan sebesar 17.958 ha dan rawa lebak sebesar 36 ha (Dinas Pertanian Provinsi Sumatera Utara, 2014). Sudirja (2007) menyatakan bahwa inceptisol merupakan ordo tanah yang belum berkembang lanjut dengan ciri-ciri bersolum tebal antara 1,5-10 meter di atas bahan induk, bereaksi masam dengan $\mathrm{pH} 4,5-6,5$, bila mengalami perkembangan lebih lanjut $\mathrm{pH}$ naik menjadi kurang dari 5,0 , dan kejenuhan basa dari rendah sampai sedang. Tekstur seluruh solum ini umumnya adalah liat, sedang strukturnya remah dan konsistensi adalah gembur. Walau kesuburan dan sifat kimia inceptisol yang relatif rendah, upaya yang dapat dilakukan yaitu dengan penanganan dan teknologi yang tepat (Gambar 1, 2, 3).

\section{Status Hara Tanah}

Jenis tanah yang diamati yaitu inceptisol. Status hara pada penelitian ini berupa hara $\mathrm{N}, \mathrm{P}, \mathrm{K}$ tanah, Hasil pengamatan lapang dan analisis contoh tanah disajikan pada Tabel 1. Dari hasil analisis, ketiga desa yakni Aras Kabu, Kelapa dan Serdang tergolong pada kriteria nilai rendah dan sedang untuk kadar hara $\mathrm{N}$.

Tabel 1. Status Hara, Tanah Sawah di Tiga Desa di Kecamatan Beringin Kabupaten Deli Serdang

\begin{tabular}{cccc}
\hline Desa & $\begin{array}{c}\mathrm{N} \\
(\%)\end{array}$ & $\begin{array}{c}\mathrm{P} \\
(\mathrm{ppm})\end{array}$ & $\begin{array}{c}\mathrm{K}_{2} \mathrm{O} \\
(\mathrm{mg} / 100 \mathrm{~g})\end{array}$ \\
\hline Aras Kabu & $0,13(\mathrm{R})$ & $19,57(\mathrm{ST})$ & $19,96(\mathrm{R})$ \\
Kelapa & $0,12(\mathrm{R})$ & $19,27(\mathrm{ST})$ & $18,56(\mathrm{R})$ \\
Serdang & $0,21(\mathrm{~S})$ & $13,19(\mathrm{~T})$ & $25,47(\mathrm{~S})$
\end{tabular}

Keterangan: SR: Sangat Rendah, R:Rendah, T:Tinggi, ST: Sangat Tinggi (BP2K, 2012)

Nilai $\mathrm{N}$ yang tergolong rendah tersebut terjadi karena sifat ikatan kimia Nitrogen mudah berubah bentuk dan mudah hilang akibat tercuci oleh air. Sehingga pada umumnya kadar hara $\mathrm{N}$ pada ketiga desa tersebut tergolong rendah. Petani di ketiga desa tersebut juga sering memberikan pupuk anorganik $\mathrm{N}$ pada fase awal tanam. Sehingga nitrogen diserap oleh tanaman. Hal ini sesuai dengan pernyataan Damanik et al., (2011) menyatakan bahwa senyawa anorganik dalam hal ini Nitrogen mudah, tercuci, bahkan dapat menguap ke atmosfir. Pernyataan ini juga didukung oleh Patti et al., 
(2013) yang menyatakan bahwa rendahnya kandungan $\mathrm{N}$ karena dipengaruhi oleh tiga faktor yaitu pencucian bersama air drainase, penguapan dan diserap oleh tanaman. Ardi et al., (2017) menyatakan nitrogen sangat mudah hilang atau terlarut baik akibat menguap ke dalam atmosfir ataupun tercuci akibat air drainase. Salah satu faktor yang membatasi pertumbuhan tanaman padi lahan sawah adalah nitrogen. Penanggulangan keterbatasan hara nitrogen di lahan sawah tadah hujan dapat dilakukan dengan pemberian bahan organik yang bersumber dari sisa panen, dikombinasikan pupuk anorganik dosis rendah. Okeleye et al., (2013) di Afrika Selatan menyatakan bahwa pemberian sisa panen kedelai dan ditambah hara $\mathrm{N}$ rendah (30 kg N ha) pada lahan sawah tadah hujan dengan kandung $\mathrm{C}$-organik dan $\mathrm{N}$-total rendah dapat meningkatkan hasil padi 33\%.

Kadar P-tersedia di desa Aras Kabu dan Kelapa tergolong sangat tinggi (19,57 ppm dan 19,27 ppm). Hal ini diakibatkan karena di desa tersebut dilakukan penanaman yang intensif setiap tahun nya dan pemberian pupuk posfat yang intensif. Sehingga menyebabkan penimbunan posfat akibat intensitasnya yang tinggi. Kandungan P-tersedia pada desa Serdang sebesar 13,19 ppm (tergololong tinggi). Hal ini disebabkan petani setiap musim tanam selalu memberikan pupuk posfat sedangkan serapan hara $P$ pada tanaman rendah. Habiburrahaman et al., (2019) menyatakan bahwa ketersediaan fosfor akan meningkat apabila intensitas penanaman semakin tinggi. Pemupukan fosfor yang intensif akan meningkatkan status hara $P$ karena tanaman tidak mampu menyerap semua $P$ tersedia pada tanah. Adiningsih (2004) menyatakan hanya sekitar $20 \%$ fosfat yang dapat diserap tanaman di lahan sawah. Abdulrachman et al., (2002), juga menyatakan di lahan sawah, hanya $20-30 \%$ saja yang dapat diserap tanaman padi saat diberikan pupuk $\mathrm{P}$. Kandungan hara $\mathrm{P}$ dan $\mathrm{K}$ lahan sawah tadah hujan biasanya bervariasi dari rendah dan tinggi. Variasi ini dapat disebabkan oleh perbedaan bahan induk tanah, pengaruh dari pengelolaan lahan dan penggunaan pupuk yang bervariasi (Kasno et al., 2016).

Berdasarkan hasil analisis tanah di lahan penelitian, kadar K-total ( $\mathrm{HCl} 25 \%$ ) tergolong rendah. Rendahnya kadar K-total terjadi akibat pencucian karena merupakan lahan sawah yang digenangi. Petani juga kurang paham manfaat pupuk Kalium akibat harga pupuk yang kurang stabil. Belum lagi para petani di daerah tersebut kurang memakai bahan organik baik berupa pupuk (kompos atau kandang) atau mengembalikan jerami pasca panen ke lahan sawah. Sulakhudin et al., (2017) juga menyatakan kadar K-total yang rendah disebabkan oleh mineral penyusun tanah miskin akan kandungan kation basa dimana kation basa tersebut tercuci akibat tingginya curah hujan. Triharto et al., (2014) juga menyatakan kadar K-total tergolong tinggi terjadi akibat pengembalian jerami padi atau sisa tanaman ke tanah. Hal ini juga didukung oleh pernyataan Makarim et al., (2007) yang menyatakan bahwa sebagai pupuk, jerami padi cukup efektif sebagai sumber kalium. Sumber air utama pada lahan sawah tadah hujan adalah air hujan, namun dengan terjadinya pergeseran pola hujan akibat perubahan iklim, ketersediaan air menjadi masalah utama dalam perencanaan pengelolaan lahan dan pola tanam. Air merupakan media reaksi hara dalam tanah, dimana hara tanah tidak tersedia pada kondisi kering dan kelebihan air. Kekeringan pada lahan sawah tadah hujan biasa terjadi pada saat tanam awal musim hujan atau musim pertama dan pada saat panen pada musim kedua. Pola curah hujan yang tidak menentu menyebabkan kesulitan saat penentuan waktu tanam dan pemupukan yang tepat. Mengejar air dengan menanam padi secepat mungkin antara lain dengan gogo rancah dan sistem culik atau dengan sumur dangkal telah dilakukan pada sebagian besar petani di Jawa (Kasno et al., 2016).

\section{KESIMPULAN}

1. Status hara di ketiga desa tersebut tergolong rendah untuk kadar N-total, tinggi untuk kadar P-tersedia dan rendah untuk kadar K-total.

2. Penggunaan pupuk $P$ dapat dikurangi sebagai implikasi dari status hara $P$ tersedia di lahan yang tinggi.

3. Untuk meningkatkan kadar hara $\mathrm{N}$ dan $\mathrm{K}$ yang rendah dapat dilakukan dengan pemberian bahan organik baik berupa pupuk (kompos atau kandang) atau mengembalikan jerami pasca panen ke lahan.

\section{DAFTAR PUSTAKA}

Abdulrachman, S., C. Witt \& R. Buresh. (2002). Pengembangan metode pengelolaan unsur hara spesifik lokasi lokakarya pengelolaan hara $P$ dan $K$ sawah. Balai Penelitian Tanaman Padi Sukamandi.

Adiningsih, J. S. (2004). Dinamika hara dalam tanah dan mekanisme serapan hara dalam kaitannya dengan sifat-sifat tanah dan aplikasi pupuk. LPI dan APPI, Jakarta.

Ardi, I., Razali \& H. Hanum. (2017). Identifikasi status hara dan produksi padi pada lahan sawah terasering dan non terasering di Kecamatan Onan Rungu Kabupaten Samosir. J. Agroekoteknologi FP USU 5(2): 338-347.

Badan Penelitian dan Pengembangan Pertanian Kementerian Pertanian (BP2KP). (2012). Petunjuk teknis analisis kimia tanah, tanaman, air dan pupuk. Edisi 2. Bogor. 204 hal.

BPS. (2014). Deli Serdang dalam angka 2014. Badan pusat statistik Kabupaten Deli Serdang, Provinsi Sumatera Utara.

Boansi, D. (2014). Yield response of rice in Nigeria: A co-integration analysis. American Journal of Agriculture and Forestry. 2(2): 15-24.

Damanik, M. M. B. D., B. E. Hasibuan, Fauzi, Sarifuddin \& H. Hanum. (2011). Kesuburan tanah dan pemupukan. USU Press. Medan.

Dinas Kominfo Kabupaten Deli Serdang. (2019). Kecamatan Beringin. https://sikesa.deliserdangkab.go.id/lihatkecamatano k? id=9. Diakses pada tanggal 1 Maret 2021.

Dinas Pertanian Provinsi Sumatera Utara. (2014). Data statistik pertanian Provinsi Sumatera Utara 2014. Pemerintah Provinsi Sumatera Utara.

Fageria, N. K. (2001). Nutrient management for improving upland rice productivity and sustainability. Communications in Soil Science and Plant Analysis. 32: 2603-2629

Gairhe, S., Shrestha, H. K. \& Timsina K. P. (2018) Dynamics of major cereal productivity in Nepal. Journal of Nepal Agricultural Research Council (4): 60-71. 
Patti, P. S., E. Kaya \& Ch. Silahooy. (2013). Analisis status nitrogen tanah dalam kaitannya dengan serapan $\mathrm{n}$ oleh tanaman padi sawah di Desa Waimital, Kecamatan Kairatu, Kabupaten Seram bagian barat. Agrologia 2(1): 51-58.

Habiburrahman, Padusung \& Baharuddin. (2019). Ketersediaan fosfor pada lahan padi sawah berdasarkan intensitas penggunaannya di Kecamatan Gerung Kabupaten Lombok Barat. Jurnal Ilmiah Budidaya, 12(01): 90-102.

Kasno, A., Rostaman, T. \& Setyorini, D. (2016). Peningkatan produktivitas lahan sawah tadah hujan dengan pemupukan hara $\mathrm{N}, \mathrm{P}$, dan $\mathrm{K}$ dan penggunaan padi varietas unggul. Jurnal Tanah dan Iklim. 40(2): 147-157.

Ling, N., Sun, Y. M., Ma, J. H., Guo, J. J., Zhu, P. \& Peng, C. (2014) Response of the bacterial diversity and soil enzyme activity in particle-size fractions of mollisol after different fertilization in a longterm experiment. Biol. Fertil. Soils (50):901-911.

Makarim, A. K., Sumarno \& Suyamto. (2007). Jerami padi : pengolahan dan pemanfaatannya. Pusat Penelitian Pengembangan Tanaman Pangan. Badan Penelitian Dan Pengembangan Pertanian.

Okeleye, K. A., Oikeh, S. O. \& Okomji, C. J. (2013). Influence of legume/rice sequence and nitrogen on nerica rice in rainfed upland and lowland ecologies of
West Africa. The African Journal of Plant Science and Biotechnology. 7(1): 21-26.

Roland N. I., M. M. Buri, S. Nakamura \& S. Tobita. (2014). Comparison of different fertilizer management practices on rice growth and yield in the Ashanti Region of Ghana. Agriculture, Forestry and Fisheries 3(5): 374-379.

Setyorini, D., S. Rochayati \& I. Las. (2010). Pertanian pada ekosistem lahan sawah. badan penelitian dan pengembangan pertanian kementerian pertanian. IPB Press. Bogor.

Sulakhudin, D. Suswati \& S. Gafur. (2017). Kajian status kesuburan tanah pada lahan sawah di Kecamatan Sungai Kunyit Kabupaten Menpawah. Jurnal Pedon Tropika. 3(1):106-114.

Supriyadi, J. Winarno, M. M. A. R. Rosariasuti \& Sumani. (2017). Penerapan analisis kesesuaian lahan untuk pengembangan tanaman janggelan di Kabupaten Pacitan. Jurnal Semar. 6(1): 79-95.

Triharto, S., L. Musa \& G. Sitanggang. (2014). Survei dan pemetaan unsur hara $\mathrm{N}, \mathrm{P}, \mathrm{K}$, dan $\mathrm{pH}$ tanah pada lahan sawah tadah hujan di Desa Durian Kecamatan Pantai Labu. J. Agroekoteknologi, 2(3): 1195-1204.

Wattoo, F. M., Rana, R. M., Fiaz, S., Zafar, S. A., Noor, M. A. \& Hassan, H. M. (2018). Identification of drought tolerant maize genotypes and seedling based morpho-physiological selection indices for crop improvement. Sains Malays, (47): 295-302. 